\title{
EFFECT OF CHRONIC EXPOSURE TO SUBLETHAL LEVELS OF MERCURY ON TOTAL PRODUCTION, PHYSIOLOGICAL FUNCTIONS AND ECONOMICAL EFFICIENCY OF TILAPIA FISH, WITH REGARD TO PROPERTIES OF PONDS WATER
}

\author{
Mohamed A. Sweilum \\ National Institute of Oceanography and Fisheries, Cairo, Egypt
}

Key words: Tilapia, growth, production, feed utilization, mortality, blood, serum, biochemical composition, mercury residues, water quality.

\section{ABSTRACT}

The effects of chronic exposure to sublethal doses of mercuric chloride $1\left(0.310,0.155\right.$ and $\left.0.078 \mathrm{mg} \mathrm{L}^{-1}\right)$ on growth rate, physiological parameters, chemical composition of tilapia species and properties of ponds water were studied for 180 days. Tilapia species (Oreochromis niloticus, Sarotherodon galilaeus and Oreochromis aureis) with an average initial size of $13 \mathrm{~cm}$ for total length and $50 \mathrm{~g}$ for body weight were stocked in fiberglass tanks $\left(6 \mathrm{~m}^{2}\right.$ area of each) at a rate of 15 fish $\mathrm{m}^{-2}$ $(1: 1: 1)$ and fed on artificial diet containing $30 \%$ protein. The physicochemical properties of ponds water were slightly varied with different mercury levels. The plankton organisms (phyto - and zooplankton) were gradually decreased with increasing the mercury concentration in fish ponds. The final body weight, daily weight gain and production of tilapia fish were significantly decreased with increasing the mercury level. The lowest values of these parameters $\left(171.5 \mathrm{~g}, 0.67 \mathrm{~g}, 1.518\right.$ ton feddan ${ }^{-1}$ for O. niloticus; $144 \mathrm{~g}, 0.52 \mathrm{~g}, 1.053$ ton feddan $^{-1}$ for $S$. galilaeus and $153.5 \mathrm{~g}$, $0.56 \mathrm{~g}$ and 0.995 ton feddan ${ }^{-1}$ for $O$. aureus) were observed in the pond containing highest mercury level $(0.310 \mathrm{mg} / \mathrm{L})$. The other growth performance (specific growth rate, percentage weight gain and normalized biomass index), feed utilization (feed conversion ratio, proteit: efficiency ratio and protein productive value) and survival efficiency of tilapia were also affected with sublethal levels of mercury. The net returns and profitability of the reared fish were also decreased with increasing mercury concentration in ponds water. The lowest hematocrit $(28.5,29.0$ 
and $30 \%$ ) and hemoglobin $(5.5,5.0$ and $5.2 \mathrm{~g} / 100 \mathrm{ml}$ blood) of the three fish species were obtained from the pond containing $0.310 \mathrm{mg} / \mathrm{L} \mathrm{HgCl}$. At the same mercury levels, the serum protein of the three fishes decreased to $7.0,6.6$ and $6.5 \mathrm{~g} / 100 \mathrm{ml}$ serum, while serum glucose increased to $81.0,79.0$ and $78.5 \mathrm{mg} / 100 \mathrm{ml}$ serum. The biochemical composition of fish muscles was also influenced with different sublethal levels of mercury, where the muscle protein and glycogen were slightly decreased and lipid increased with increasing the mercury level. The mercury residues in liver, gills and muscles of the reared fish were increased with increasing the mercury concentration in ponds water and its value in liver was higher than that in gills and muscles.

\section{INTRODUCTION}

Recently, attention has been focused on fish farming, since it has a great potential for achieving new sources of fish production and since most natural resources are overexploited. So, the interest in aquaculture has been directed mainly towards the development of pond culture (Ishak, 1985). Tilapia species are successfully cultured in the Egyptian fish farms, since they have high growth rate, can be fed on artificial diets and have high tolerance to different water quality (Bayoumi, 1987). Fish cari also be a source of threat to human health by transporting the toxic materials directly to the consumers. Since heavy metals are widely distributed in aquatic habitats due to the industrial effluents and the wide use of chemicals in agriculture, the aquatic habitats with their water quality are considered the main factor controlling the state of health and disease of fish. The toxicity of heavy metals and their effects on physiological and biochemical parametes of freshwater fish have been reported by many investigators (Ghazaly \& Said, 1995; Iqbal et al., 1997; El-Nagar et al., 2001; Mahmoud 2002). Mercury, like other heavy metals, may find its way to the water system and affects aquatic life, particularly fish, through its interference with their metabolic processes (Kumari and Banerjee, 1993). Mazhar et al. (1987) exposed the Nile catfish (Clarias gariepinus) to sublethal levels of mercuric chloride and noticed a progressive fall in RBCs count, hematocrit and an increase in WBCs count. Similarly, Misra and Behera (1992) found the decline of erythrocyte count, hematocrit and hemoglobin in blood of Channa punctatus on exposure to sublethal concentration of mercuric chloride. Same observations were also mentioned by Shakoori et al. (1994) for grass carp (C. idella) and Marie (1999) for Nile tilapia (O. niloticus). The 
present study was conducted to determine the effects of sublethal doses of mercury on growth rate, physiological properties and economical efficiency of three tilapia species ( $O$. niloticus, $S$. galilaeus and $O$. aureus), in addition to its effects on water quality and plankton fertility in fish rearing ponds.

\section{MATERIALS AND METHODS}

Site of work and fish used

The present work was carried out in rectangular fiber glass tanks $(3 \times 2 \mathrm{~m}$ ) with $0.85 \mathrm{~m}$ depth. These tanks were filled with freshwater and supplied with sublethal doses of mercuric chloride as follows; the control one was maintained without mercury, the other tanks contained 0.310 , 0.155 and $0.078 \mathrm{mg} \mathrm{L}^{-1}$, while the tanks were duplicated with the same experimental treatments. The water in ponds was continuously aerated by mean of an electric compressor, faeces and other remains were removed daily by sucking. The fish used were Oreochromis niloticus, Sarotherodon galilaeus and Oreochromis aureus with an average starting body weight of $50 \mathrm{~g} / \mathrm{fish}$ and $13 \mathrm{~cm}$ for total length. The fish were stocked in tanks at a rate of 15 fish $\mathrm{m}^{-2}$ (90 fish pond ${ }^{-1}$ ), 30 O. niloticus, $30 \mathrm{~S}$. galilaeus and 300 . aureus. The supplementary feed was pelleted diets containing $30 \%$ crude protein and formulated from fish meal, soybean, rice bran, yellow corn and sunflower oil (commercial diets). The fish fed six days a week, once per day at a level of $3 \%$ of the average body weight.

\section{Physico-chemical and hydro-biological aspects}

Water temperature, dissolved oxygen and $\mathrm{pH}$ value were daily determined ( 9.00 am and $2.00 \mathrm{pm}$ ) by using a simple thermometer, oxygenometer (Cole Parmer Model 5946) and pH meter (Orion Digital Model 210). Total alkalinity, ammonia, nitrate and phosphate were monthly estimated, using methods described by Arnold et al. (1980). Samples of plankton were taken biweekly from 10 liters of tanks water. The phytoplankton organisms were collected by a fine nylon net of 20 micron mesh size, then identified and counted by Sedwick Rafter Counting Cell, through a research microscope (200 X). The zooplankton individuals were collected, using a nylon net of 50 micron mesh size and counted by Tray Counting Cell through microscope (100 X).

\section{Growth and feed utilization}

The total length $(\mathrm{cm})$ and body weight $(\mathrm{g})$ of reared fish (15 fish from each species in each treatment) were measured biweekly. Specific growth rate (SGR), percentage weight gain (PWG), normalized biomass 
index (NBD), feed conversion ratio (FCR), protein efficiency ratio (PER) and protein productive value (PPV) were calculated according to the following equations;

$S G R=(\operatorname{Ln}$ final weight - Ln initial weight $) \times 100 /$ Period (days)

PWG $=($ Final weight - Initial weight $) \times 100 /$ Initial weight

$\mathrm{NBI}=$ Final weight - Initial weight $/ 100$

FCR $=$ Food consumed $(\mathrm{g}) /$ Weight gain $(\mathrm{g})$

PER $=$ Weight gain $(\mathrm{g}) /$ Protein consumed $(\mathrm{g})$

PPV = Increasing of body protein (g) / Protein consumed $(\mathrm{g}) \times 100$

Meanwhile, the total survival rate (TSR) and condition factor $(k)$ of experimental fish in each treatment were estimated by applying these formulae;

TSR $=$ Survived fish number $\times 100 /$ Total fish number

$\mathrm{K}=$ Body weight $\times 100 /$ (Total length) $^{3}$.

\section{Production and economical efficiency}

The total fish production and economical efficiency (net returns and profitability) of rearing ponds were determined in different treatments at the end the experiment (180 days) according to the following equations:

Fish production (ton feddan ${ }^{-1}$ ) $=4200$ [Weight gain (g) $\times$ Number. of survived fish $/ 10^{6}$ ]

Net returns (LE feddan $\left.{ }^{-1}\right) \quad$ = Price of produced fish $(\mathrm{LE})-$ Total costs (LE)

Profitability (percent)

$=$ Price of produced fish (LE) / Total costs (LE) $\times 100$

(feddan $=4200 \mathrm{~m}^{2}$, hectar $=10000 \mathrm{~m}^{2}$, hectar $=2.38$ feddans $)$

\section{Blood and biochemical composition}

The blood samples (10 fish were examined from each species in each treatment) were taken over heparinized vials by severing the caudal peduncle of fish (Dabrowska et al., 1989). The hematocrit percent was measured by drawing the blood directly from fish into a heparinized hemopipette, then centrifuged at 3000 r.b.m. (Hesser, 1960). Hemoglobin content was estimated by Van Kampen \& Zijfstra method (1961). Serum glucose was determined by using Boehringer Manneim Kits as described by Trinder (1969) and serum lipid by Zollner \& Kirsch method (1962). Protein in serum and muscles were determined according to Gornall et al. (1949). Glycogen in fish muscles was measured by using the anthrone reagent (Handel, 1965), while total lipid in muscles was extracted by 
mixture of chloroform with methanol (2:1) and estimated using Bligh \& Dyer (1959) method.

Mercury residues in fish tissues

The examined tissues of fish (liver, muscles and gills) were completely dried at $75^{\circ} \mathrm{C}$ for about 48 hours. Half gram of dry weight of each sample was digested with the digestion solution $\left(65 \% \mathrm{HNO}_{3}\right.$ and 30 $\% \mathrm{H}_{2} \mathrm{O}_{2}$ ) using the digestor (Milestone, MLS-1200 mega) and microwave digestion system with MDR technology. Concentration of mercury $(\mathrm{Hg})$ was determined by the atomic spectrophotometer (Perkin-Elmer, 2380, Germany).

Statistical analysis

The differences between means of experimental and control values in different treatments were considered unsignificant if $P>0.05$, significant if $P<0.05$ and highly significant if $P<0.01$ using t-test of significance as described by Berlly \& Lindgren (1990) with applying the following equations;

Calculated value $=\bar{X}_{1}-\bar{X}_{2} / \sqrt{(S E)_{1}^{2}+(S E)_{2}^{2}}$

Standard error $(\mathrm{SE})=$ Standard deviation $(\mathrm{SD}) / \sqrt{n}$

where, $X_{1}=$ Mean of the first group.

$\mathrm{X}_{2} \quad=$ Mean of the second group.

$\mathrm{SE}_{1} \quad=$ Standard error of data in first group.

$\mathrm{SE}_{2}=$ Standard error of data in second group.

$\mathbf{n} \quad=$ Number of cases in each group.

\section{RESULTS}

\section{a- Effect of mercury on water quality and plankton}

The present results (Table 1) showed that water temperature was not clearly varied with different sublethal levels of mercuric chloride, while the dissolved oxygen was slightly decreased with increasing mercury concentration in fish ponds and had its lowest value $(2.61 \pm 0.36$ $\left.\mathrm{mg} \mathrm{L} \mathrm{L}^{-1}\right)$ in pond containing highest mercury level $\left(0.310 \mathrm{mg} \mathrm{L}^{-1}\right)$. The other chemical properties of ponds water (alkalinity, ammonia, nitrate, phosphate and $\mathrm{pH}$ value) were increased with the highest mercury concentration to $186.0,0.7,0.51,3.75 \mathrm{mg} \mathrm{L}^{-1}$ and 8.61 , respectively. Table (1) reveales also that, the number of phytoplankton (Chrysophyta or diatoms, golden yellow algae; Chlorophyta, green algae and Cyanophyta, blue green algae) and zooplankton (Ciliophora, Cilliata spp; Rotifera, Brachionus sp.; Cladocera, Daphnia sp. and Copepoda, Cyclops sp.). 
organisms were decreased with increasing of sublethal doses of $\mathrm{HgCl}_{2}$ in ponds water. The lowest numbers of phyto and zooplankton organisms $\left(145,220,105,135 \mathrm{cell} / \mathrm{m}^{3}\right.$ for phytoplankton groups and $61,75,44$ cell $/ \mathrm{m}^{3}$ for zooplankton individuals, respectively) were observed at highest mercury level $\left(0.310 \mathrm{mg} \mathrm{L}^{-1}\right)$.

\section{b- Effect of mercury on growth and feed utilization}

The influences of mercuric chloride levels on the final body weight (FBW) and daily weight gain (DWG) of the three tilapia species were summarized in Table (2), the lowest values $(171.5,0.67 \mathrm{~g} ; 144.0$, $0.52 \mathrm{~g}$ and $153.5,0.56 \mathrm{~g}$ for the three fish species, respectively) were observed at highest mercury level $\left(0.310 \mathrm{mg} \mathrm{L}^{-1}\right)$. As shown in Table (3), the specific growth rate (SGR) and normalized biomass index (NBI) were gradually decreased with increasing the mercury level in ponds, their minimum values $(0.67,1.21$ for $O$. niloticus; $0.59,0.94$ for $S$. galilaeus and $0.60,1.02$ for $O$. aureus) were obtained from the pond containing $0.310 \mathrm{mg} \mathrm{L}^{-1} \mathrm{HgCl}_{2}$. The feed conversion ratio (FCR) of reared fish was not affected with different mercury levels in ponds water, while the values of protein efficiency ratio (PER) and protein productive value (PPV) were decreased to $1.02,1.27 ; 0.95,1.01$ and $0.96 ; 0.94$ for the three fish species respeetively when the $\mathrm{HgCl}_{2}$ level increased to 0.310 $\mathrm{mg} \mathrm{L}^{-1}$. Table (3) showed also that the survival rate was decreased with increasing the mercury level in ponds water and had its lowest values $\left(60.00,53.33\right.$ and $46.67 \%$ for three fish species) at $0.310 \mathrm{mg} \mathrm{L}^{-1} \mathrm{HgCl}_{2}$. Meanwhile, the condition factor of fish was increased to $2.62 \pm 0.52$ for Nile tilapia, $2.47 \pm 0.50$ for galilae fish and $2.55 \pm 0.50$ for aurea fish in the pond with highest mercury level $\left(0.310 \mathrm{mg} \mathrm{L}^{-1}\right)$.

c- Effect of mercury on production and economical efficiency .

The total fish production (TFP), net return (NR) and profitability (P) of reared fish were alșo affected with different levels of mercuric chloride (Table 4). Their values were slightly decreased with increasing the mercury concentration in ponds water and reached to its minimum limit $\left(1518,1053,995 \mathrm{~kg}\right.$ feddan $^{-1} ; 2486,331,227 \mathrm{~L} . \mathrm{E}$. $\quad$ fẹddan $^{-1}$ and $0.21,0.03,0.02 \%$ for the three fish species, respectively) at the pond with $0.310^{\circ} \mathrm{mg} \mathrm{L}^{-1} \mathrm{HgCl}_{2}$.

\section{d- Effect of mercury on blood and biochemical composition}

The data presented in Table (5) indicated that the blood parameters, serum analysis and biochemical composition of fish muscles were highly affected with sublethal levels of mercuric chloride. The hematocrit and hemoglobin contents were decreased to $28.5,29.0,30.0 \%$ 
and $5.5,5.0,5.2 \mathrm{~g} / 100 \mathrm{ml}$ blood for the three fish species at highest mercury level $\left(0.310 \mathrm{mg} \mathrm{L}^{-1}\right)$. On the other hand, glucose and lipid levels in serum of the three fish species were increased to $81.0,79.0,78.5 \mathrm{mg}$ $1100 \mathrm{ml}$ serum and $3.2,3.1,3.35 \mathrm{~g} / 100 \mathrm{ml}$ serum with increasing the mercury concentration to $0.310 \mathrm{mg} \mathrm{L}^{-1}$ as compared with the control group (without mercury). In the contrast, the serum protein was decreased to $7.0,6.6$ and $6.5 \mathrm{~g} / 100 \mathrm{ml}$ serum (for the three fish species) at highest mercury level $\left(0.310 \mathrm{mg} \mathrm{L}^{-1}\right)$. The protein and glycogen in fish muscles had its minimum values $(12.5,12.0,12.0 \mathrm{~g} / 100 \mathrm{~g}$ fresh tissue and 0.86 , $0.90,0.85 \mathrm{mg} / 100 \mathrm{~g}$ fresh tissue for the three fish species) in pond containing $0.310 \mathrm{mg} \mathrm{L}^{-1} \mathrm{HgCl}_{2}$, while the total lipid had its maximum values $(9.1,8.9$ and $9.0 \mathrm{~g} / 100 \mathrm{~g}$ fresh tissue respectively).

e- Mercury residues in fish tissue

Table (5) also cleared that the greatest bioaccumulation of mercury metal was observed firstly in the liver then in gills and lastly in fish muscles. The maximum values of mercury residue $(2.42,3.10$ and $2.65 \mathrm{mg} / \mathrm{g}$ dry weight for the three fish species) were observed for fish reared in pond containing $0.310 \mathrm{mg} \mathrm{L}^{-1}$ mercuric chloride.

\section{DISCUSSION}

- The present study revealed that, the sublethal levels of inorganic mercuric chloride $\left(\mathrm{HgCl}_{2}\right)$ caused a disturbance for water quality (physico-chemical properties) in fish ponds. The dissolved oxygen decreased while other chemical properties and $\mathrm{pH}$ increased. Similar observations were detected by Draz et al. (1993) who mentioned that heavy metals (including mercury) may find their way to the water system and affect on the physico-chemical parameters (water temperature, $\mathrm{pH}$ value, dissolved oxygen, organic matter and chloride content) of ponds water. Similarly, Perschbacher \& Wurts (1999) reported that the total alkalinity and other chemical properties in ponds of channel catfish were gradually increased with increasing the heavy metals concentration, while dissolved oxygen decreased. On the other hand, mercury, like other heavy metals, influences the aquatic life (plankton organisms) of water in fish ponds. Starodub et al. (1987) cited that individual and combined heavy metals toxicity lead to decreasing of freshwater green algae in fish ponds. In addition, Siriwardena et al. (1995) noticed that the heavy metals (including mercury) caused a decline in number of small aquatic organisms (phyto and zooplankton) in fish ponds.

The present work also showed a decreasing in growth performance in tilapia species with increasing mercury level in ponds 
water. This may be attributed to these factors; a- the mercury level reduced the dissolved oxygen in ponds due to falling of chlorophyta decreasing of photosynthesis process). b- mercury decreased the natural food organisms (phyto and zooplankton) in fish ponds c- mercury reduced the activities of digestive enzymes in tilapia bodies (Sastry and Gupta, 1979).

It was also noticed that there is no clear differences between the feed conversion ratio in control fish and fish under experimental treatments, while the protein efficiency ratio and protein productive value were decreased at highest level of $\mathrm{HgCl}_{2}$. Similar observations were detected by Barak and Mason (1990) on five species of freshwater fish from Eastern England and Draz et al. (1993) on three tilapia species. They added that the highest sublethal level of mercury $\left(0.310 \mathrm{mg} \mathrm{L}^{-1}\right)$ affected also on fish bone, leading to decreasing of total length of reared fish (dwarfism cases) consequently reduce the condition factor which is a relation between the total length and body weight.

Furthermore, the decreasing of fish production and profitability of tilapia species reared in ponds containing sublethal levels of mercury as cleared in the present study, may be due to the reduced growth rate, metabolic activity and increased mortality of fish. Draz et al. (1993) reared three species of tilapia under chronic exposure to some heavy metals and noticed that there were a significant difference in final body weight between treated and non treated fish. They added that the growth parameters of reared fish were gradually decreased with increasing the heavy metal level in ponds water.

The present results also showed that the hematocrit and hemoglobin of tilapia fish were decreased at highest mercury level, while serum glucose was significantly increased. The decreasing of hematocrit and hemoglobin in different freshwater fish (tilapia species) as a result of exposure to sublethal concentrations of mercury was observed also by Misra \& Behera (1992) on Channa punctatis; Kumari \& Banerjee (1993) on Clarias batrachus, Shakoori et al. (1994) on Ctenopharyngodon idella and Marie (1999) on Oreochromis: niloticus. These investigators attributed the decrease in hematocrit and hemoglobin to the decreased production of erythrocytes coupled with an enhanced rate of their destruction in the hemopiotic organs and to interhepatic, interasplenic hemorrhage, due to the action of heavy metal accumulation. The significant increase in serum glucose and decreasing in muscle glycogen of tilapia fish, when exposed to mercury may be attributed to a-inhibition 
of gluconeogenesis processes that lead to mobilization of liver glycogen into blood glucose (Salmeron et al. 1990), b-increasing secretion of catecholamines from the adrenal medulla, which in turn enhance the breakdown of glycogen and increase blood sugar (El-Sabbagh, 1996), c-accumulation of heavy metals in the pancreatic islets and damage to the insulin produced Beta cells (Zaghloul, 1997). Concerning the present experiment, exposure of tilapia species to mercury caused a decrease of serum and muscle protein. This agrees with that postulated by Saeed (1998) on O. niloticus and El-Nagar et al. (2001) on $\quad O$. aureus. In contrast, lipid in serum and muscles of fish was increased with increasing of mercury level in ponds water in the present study. A similar finding was reported by Ghazaly \& Said (1995) in O. niloticus reared under chronic exposure to mercury concentrations.

The increasing of mercury residues in fish tissues (liver, gills and muscles) with increasing mercuric chloride levels in fish ponds and its highest concentration in liver than that in gills and muscles was also noticed by Salah El-Deen et al. (1996) who mentioned that, the greatest mercury residues were observed in fish liver due to the high movement of mercury from different tissues to the liver for detoxification.

\section{CONCLUSION}

The present investigation demonstrated that the sublethal concentrations of inorganic mercury $\left(\mathrm{HgCl}_{2}\right)$ in the aquatic areas deteriorate fish culture systems and leads to degradiation of water fertility in fish farms. Mercury toxicity decreased the growth rate and production of tilapia species, consequently reducing economical efficiency of rearing ponds. Mercury also caused an increase of serum glucose and lipid coupled with decreasing hematocrit, hemoglobin, serum protein and muscles protein and glycogen. Bioaccumulation of mercury was much higher in fish liver than in gills and muscles.

\section{REFERENCES}

Abbaș, H. H. and Mahmoud, H. M. (2002). Hematological and biochemical changes in Oreochromis aureus and Clarias gariepinus exposed to mixture of copper and lead. J. of Egypt. Ger. Soc. of Zool., 38: 195-211. 
Arnold, E:Q.; Joseph, J.C. and David, J. (1980). Standard Methods for the examination of water and waste water, 15 edn. American Public Health Association, Washington, DC, USA.

Barak, N. A. and Mason, C. F. (1990). Mercury, Cadmium and Lead concentrations in five species of freshwater fish from Eastern England. Sci. Total Envir., 92: 257-263.

Bayoumi, A.R. (1987): Development of fish farming in Egypt, Cage culture. Institute of Oceanography and Fisheries, Cairo, Egypt and IDRC, Canada, Report 5 (Phase 11);63 pp.

Berlly, D.A. and Lindgren, B.W. (1990). Statistics, Theory and Method. Brooks / Cole Publishing Company Pacific Grover, California, pp. 8, pp: 93-121, 186, 243, 364, 397.

Bligh, E.G. and Dyer, W.T. (1959). A rapid methods of total lipid extraction and purification. Can. J. of Bio. and Phys., 37: 911 917.

Dabrowska, H.; Burgdrof; K. and Gunther; K. (1989). Interaction between dietary protein and magnesium level in tilapia (Oreochromis niloticus). Aquacult., 76:277-291.

Draz, A.A.; Samara, I.A. and El-Sarha, A.I. (1993). Effects of chronic exposures to copper on production and total residues among tilapia species. Bull. Nat. Inst. of Ocean. \& Fish., 19: 351-367.

El-Nagar, G.O.; Salah El-Deen, M.A. and Abbas, H.H. (2001). Effect of copper and lead toxicity on physiological characteristics of blue tilapia (Oreochromis aureus) and African catfish (Clarias gariepinus). J. of Egypt. Ger. Soc. of Zool. 34: 225-224.

El-Sabbagh, H. S. (1996). Biochemical and hematological changes in Nile tilapia (Oreochromis niloticus) exposed to copper. Vet. Med. J. Giza, Egypt, 44: 23-30.

Ghazaly, K.S. and Said, K.M. (1995). Physiological characteristics of Tilapia nilotica (Oreochromis niloticus) under acute stress of copper. J. of Egypt. Ger. Soc. of Zool., 16: 287-301. 
Gornall, A. C.; Bardowill, C. J. and David, M. M. (1949). Determination of serum protein by Burit reagent. $\mathrm{J}$ of Bio. and Chem., 177: 751 pp.

Handel, E. V. (1965). Estimation of glycogen in small amount of tissue. Ana. Biochem. J., 8: 165-265.

Hesser, E. F. (1960). Methods for routine fish hematology. Prog. Fish Cult., 22: 164-171.

Iqbal, M. J.; Ali, S. S. and Shakoori, A. R. (1997). Toxicity of load in freshwater fish (Cirrhina mrigala). Hematological changes. J. of Envir. Mon., 7:139-143.

Ishak, M. M. (1985). Development of fish farming in Egypt. Cage and Pen (enclosure) culture. Institute of Oceanography and Fisheries. Egypt and IDRC Canada Report No.3, Phase II,. $64 \mathrm{pp}$.

Kumari, M. and Banerjee, V. (1993). Effect of lethal and sublethal levels of mercury on the blood of catfish (Clarias batrachus). Envir. Ecol., 11: 465-467.

Marie, M. A. S. (1999). The role of increasing calcium hardness on the physiological responses of the Nile tilapia (Oreochromis: niloticus) induced by zinc and mercury individually and in mixture. J. of Egypt. Ger. Soc. of Zool., 28: 219-235.

Mazhar, F.M.; Ashry, M.A. and Kadry, S.M. (1987). Effects of environmental pollution by mercury on blood parameters of the Nile catfish (Clarias lazera). Proc. Zool. Soc. Egypt, 13: 247256.

Misra, S.K. and Behera, S.C. (1992). Evaluation of toxic effects of mercuric chloride on hematological parameters of a freshwater fish (Channa punctatus, Bokh). Envir. Ecol., 10: 394-396.

Perschbacher, P.W. and Wurts, W.A. (1999). Effects of calcium and magnesium hardness on acute copper toxicity to juvenile channel catfish (Ictalurus punctatus). Aquacult., 172: 275-280. 
Saeed, R.M.A. (1998): A restoration toward toxic impact and bioaccumulation of zinc, cadmium and copper in the Nile tilapia (Oreochromis niloticus). J of Egypt. Ger. Soc. of Zool., 25: 383398.

Salah El-Deen, M.A.; Sharada, H.M. and Abdu El-Ella, S.M. (1996). Some metabolic alternation in grass carp (Ctenopharyngodon idella) induced by exposure to cadmium. J Egypt. Ger. Soc. Zool., 21: 441-457.

Salmeron, F.P.; Melednez, C. M. and Martinez, T. L. (1990). Heptotoxic and nephrotoxic effects of lead on the tilapia (Sarotherodon aureus). J. Ana. de la Esc. Nac. de Cien. Biol., Mexico, 33: 147158.

Sastry, K.V. and Gupta, P.K. (1979). The in-vivo effect of mercuric chloride on some digestive enzymes of a freshwater teleost fish (Channa punctatus). Bull. Envir. and Cont. Toxicol., 22: 9-16.

Shakoori, A.R.; Iqbal, M. J.; Mughal, A. L. and Ali, S. S. (1994). Biochemical changes induced by inorganic mercury on the blood, liver and muscles of freshwater chinese grass carp (Ctenophryngodon idella). J. Ecotoxicol. \& Envir. Mon, 4: 8192.

Siliswardena, P. P.; Rana, K. J. and Baird, O. J. (1995). A method for partitioning cadmium bioaccumulated in small aquatic organisms. Envir. Toxicol. and Chem., 14: 1575-1577.

Starodub, M. E., Wong, P. T., Myfield, C. I. and Chau, Y. K. (1987). Influence of complexation and $\mathrm{pH}$ on individual and combined heavy metal toxicity to a freshwater green algae. Can. J. of Fish. and Aqautic Sci., 44: 1173-1180.

Trinder, P. (1969).Determination of glucose in blood serum or plasma by enzymatic colorimetric method. Ann. Clin. of Biochem., 6: 24 pp. 


\section{EFFECT OF EXPOSURE OF MERCURY ON PHYSIOLOGICAL FUNCTIONS OF TILAPIA FISH}

Van Kampen, E. T. and Zijfstra, W. G. (1961). Recommendation for hemoglobinametr in human blood. Clin. and Chem. Arsu, $6:$ $338 \mathrm{pp}$.

Zaghloul, K. H. (1997). Studies on the effect of water pollution along different sites of the River Nile on the survival and production of some freshwater fish. Ph.D. Dissertation, Cairo University, Egypt.

Zollner, N. and Kirsch, K. (1962). Determination of lipids (micromethod) by means of the sulfophosphovanillin reaction common to many natural lipids. Z. Ges. Exper. Med., 135: 545-561. 


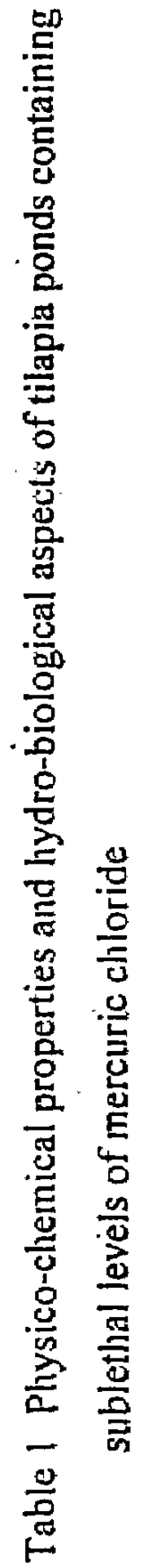

\begin{tabular}{|c|c|c|c|c|c|c|c|c|c|c|c|c|c|c|c|c|c|c|c|c|}
\hline ه & 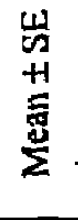 & 숭 & 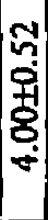 & $\frac{8}{8}$ & $\left\{\begin{array}{l}0 \\
0 \\
+1 \\
0 \\
0\end{array}\right.$ & $\begin{array}{l}0 \\
0 \\
+ \\
0 \\
0\end{array}$ & $\left\{\begin{array}{l}5 \\
0 \\
0 \\
0\end{array}\right.$ & $\begin{array}{l}0 \\
0 \\
0 \\
0 \\
0\end{array}$ & & & $\begin{array}{l}- \\
+1 \\
\pm\end{array}$ & $\begin{array}{l} \pm \\
+1 \\
0 \\
m\end{array}$ & 我 & $\left\{\begin{array}{l}n \\
+ \\
y \\
y\end{array}\right.$ & & $\begin{array}{l}+ \\
4 \\
5\end{array}$ & $\underset{r}{5}$ & & & 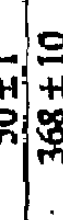 \\
\hline$\infty$ & & & & & & $k$ & & & & & & & & & & & & & & \\
\hline
\end{tabular}

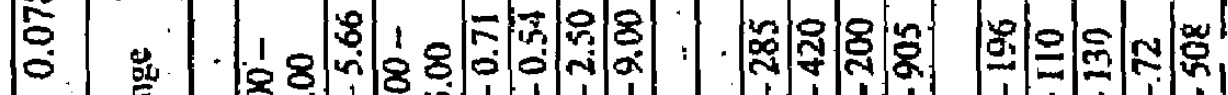

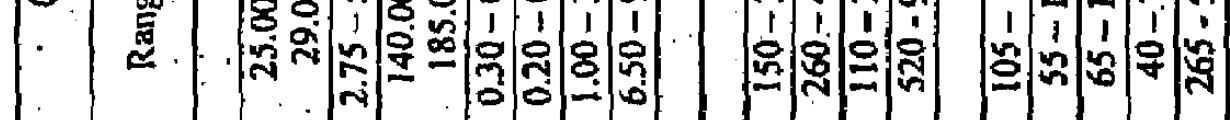

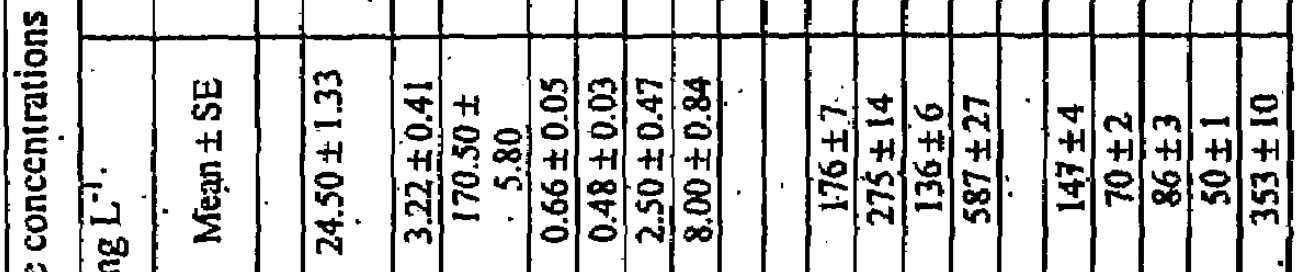

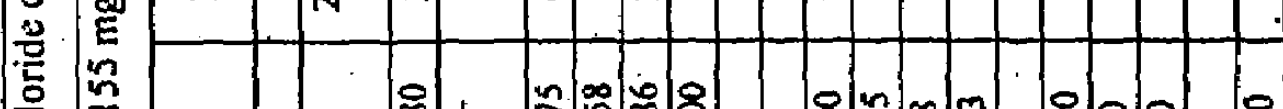

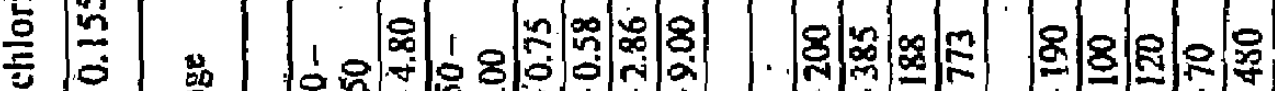

1.

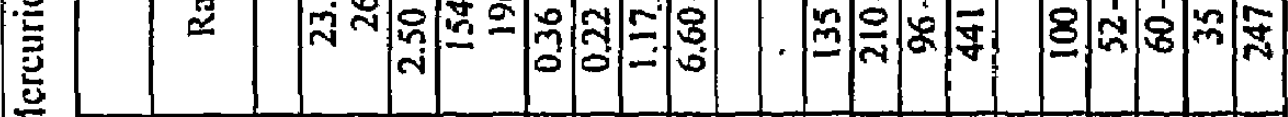

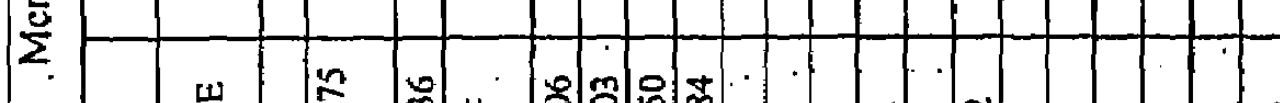

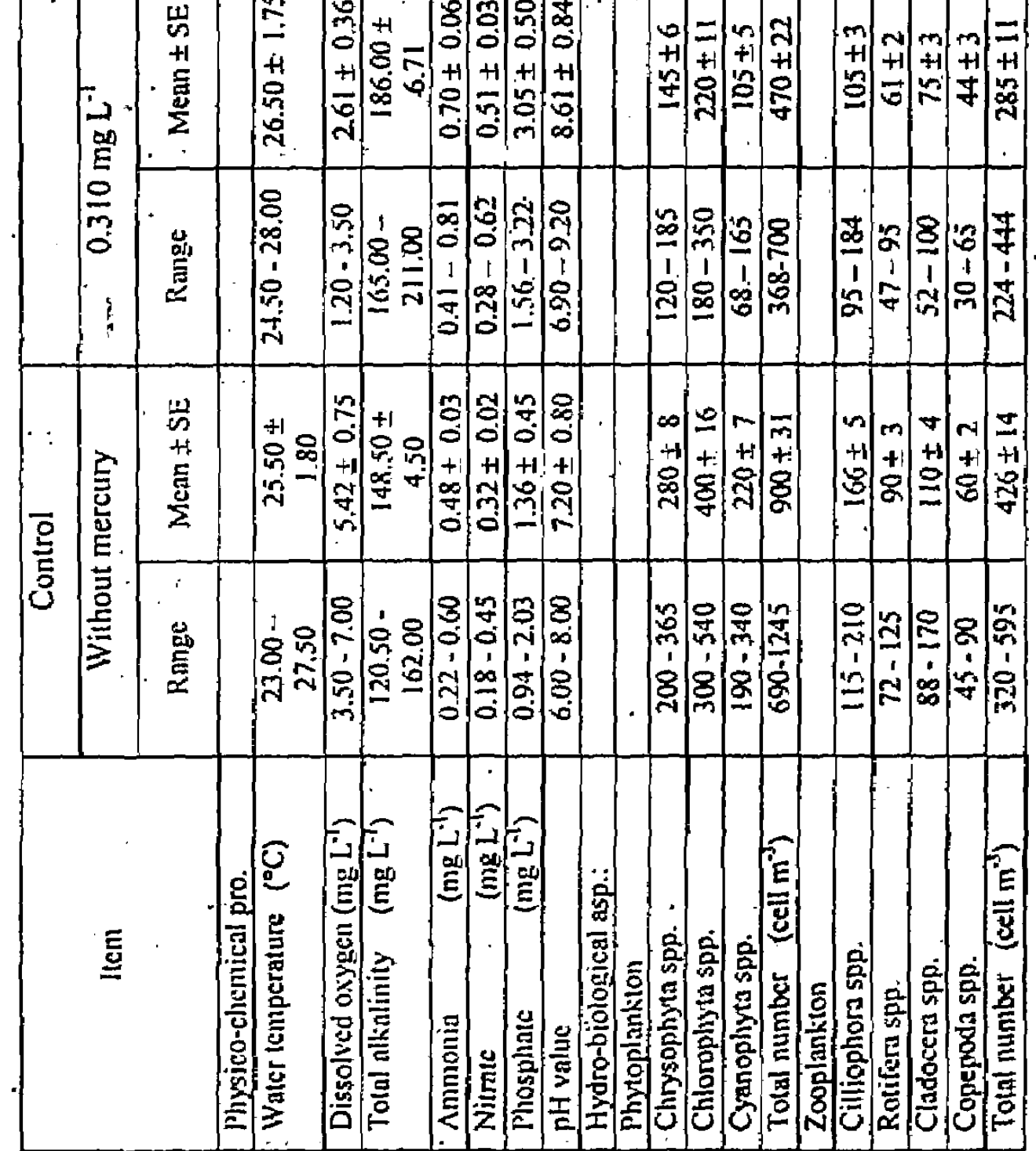




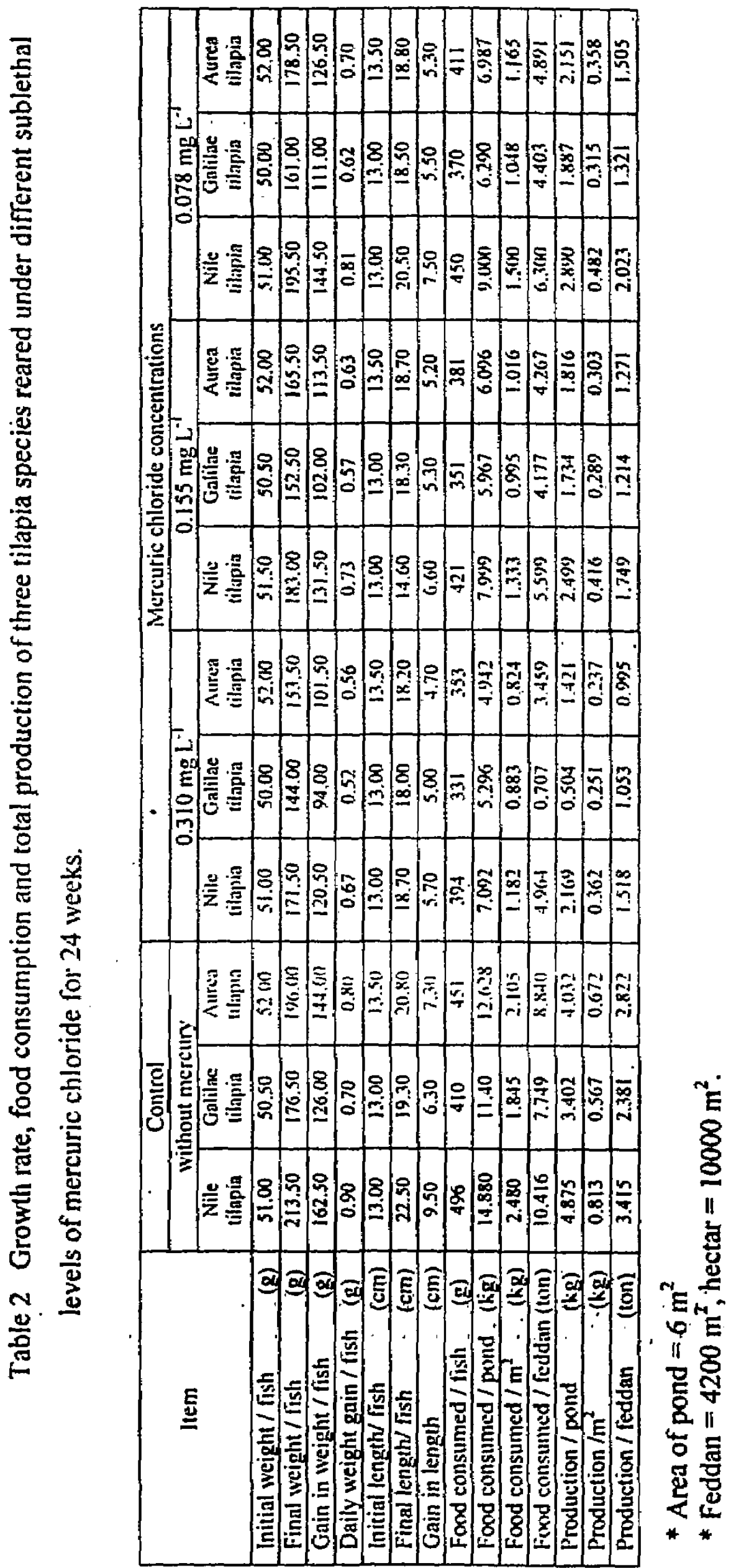




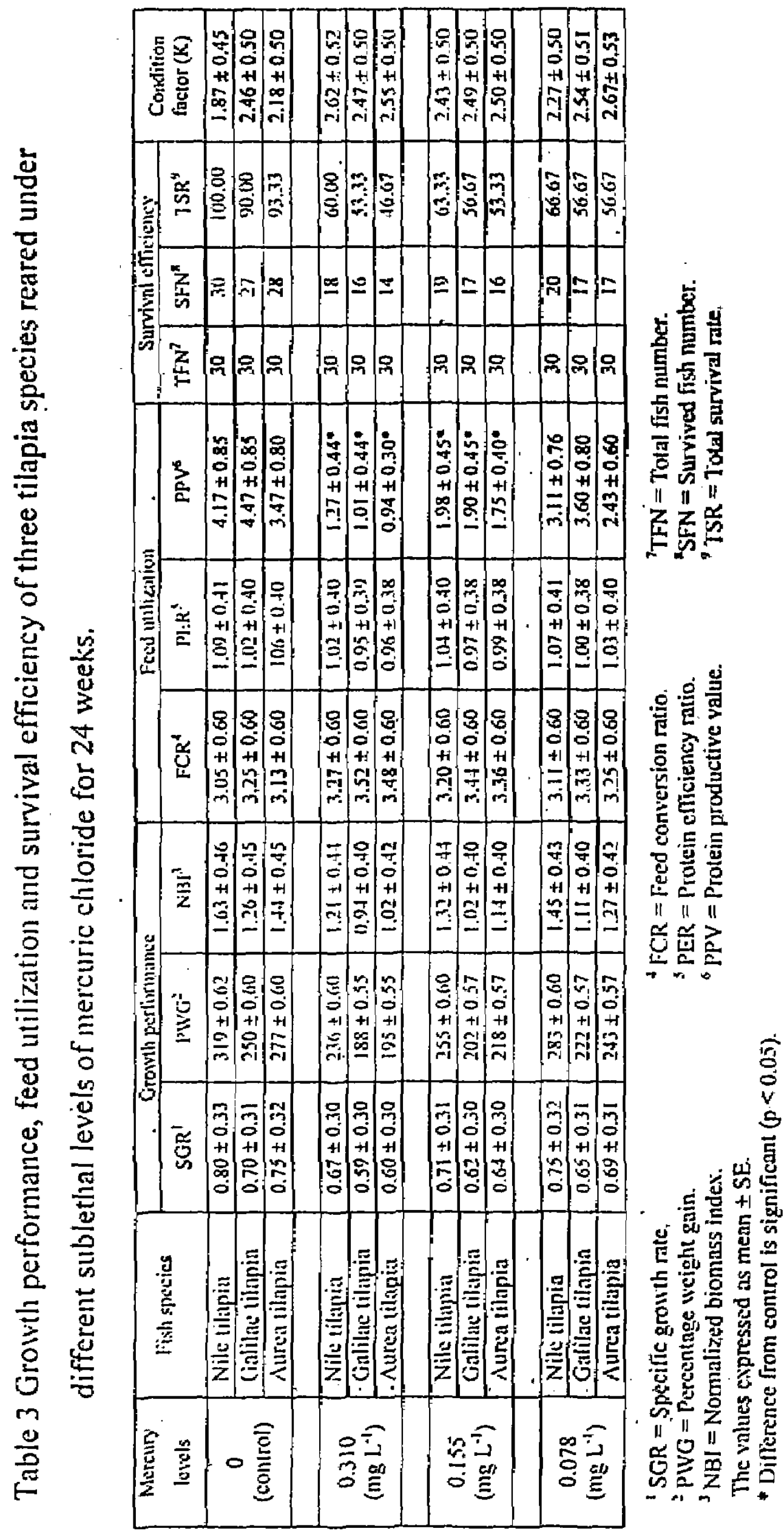




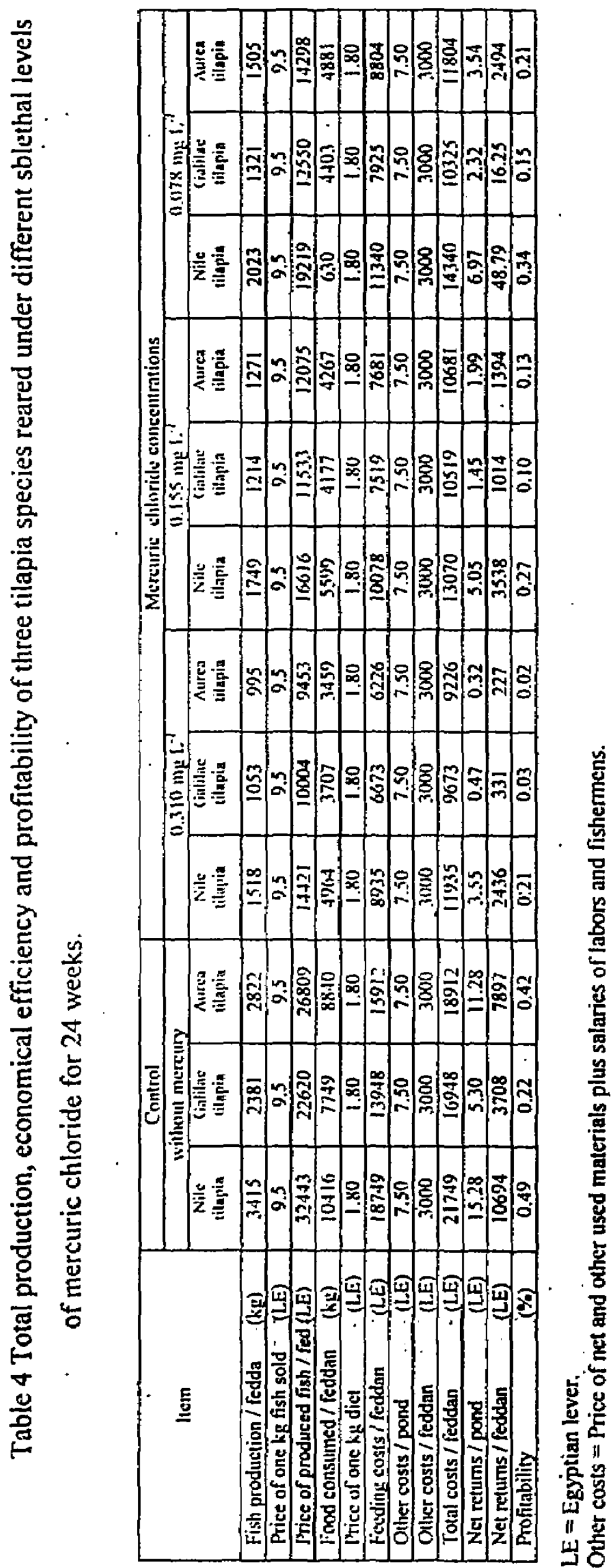




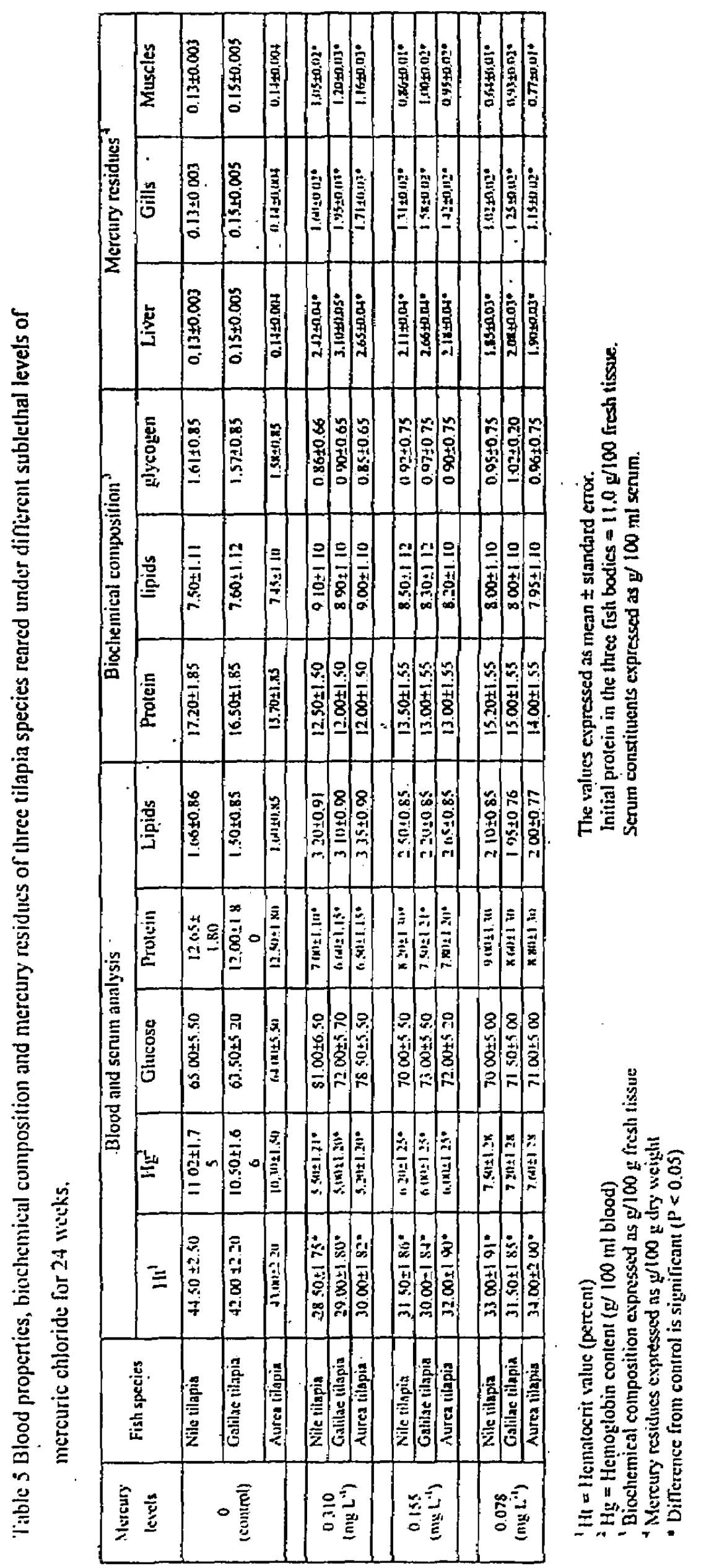

